\title{
Walking on two legs
}

THE regular two-way flow of scientists and technologists that has now been established between the People's Republic of China and the rest of the world has led to some fascinating discoveries about the way in which Chinese research is done and how it is managed. Now the Organisation for Economic Co-operation and Development (OECD) has produced a large-scale document, Science and Technology in the People's Republic of China, which attempts to produce an integrated viewpoint on the nature and evolution of China's science and technology system. It should be widely read, particularly by those just about to embark on a visit to China.

OECD's Committee for Scientific and Technological Policy has, of course, been analysing national science policies for many years, generally at the invitation of member countries who have, during the course of the analysis, staged a 'confrontation' with the OECD examiners. In this case, no Chinese were present at the seminar of thirty-odd science-policy experts and sinologists from a dozen countries out of which this report arose. But although it is the work of outside observers and it lacks some detailed information (which probably is all but inaccessible in China itself), the document does most clearly outline the dilemma of organising science and technology in an immense, partly developed nation with major demands both on the urban and rural sector and with a fluctuating but potent ideology in the driving seat.

China seems to live perpetually under the influence of two opposing forces; walking on two legs is how the Chinese describe their attempts to come to terms with these polarities. Elitism and egalitarianism; old and new; 'expertness' and 'redness'; theory and practice; ideology and technology; Mao and non-Mao. And even these poles are very mobile and slippery, as Simon Leys recently demonstrated in the New York Review of Books with a mischievous juxtaposition of some of the late Chairman's mutually-contradictory thoughts. Perhaps the fundamental question is whether China is governable at all-'if not governed firmly, it is in danger of falling into anarchy and fragmentation. If governed firmly, it is in danger of being strangled by the very growth of bureaucracy this tends to bring with it', was the way one participant in the seminar put it.

Small wonder then that China's recent scientific and technological past should be marked by grotesque ups and downs. During the Great Leap Forward and the two preceding years (1956-60), university enrolments more than doubled, and the science budget more than quadrupled. But the country wasn't yet equipped to use its graduates and in the next few years enrolments declined by about a third as 'realism' took over and smaller growth was accepted. But then came the next violent change, the Cultural Revolution of 1966. This time universities were all but annihilated for a period of a couple of years as the higher educational system came under attack on all fronts, including its alleged discrimination against workers and peasants. In the recovery period of the past few years students now go through at least two years of manual labour in rural areas before proceeding to higher education.

Science itself was relatively well protected at the beginning of the Cultural Revolution, by the "16-point Directive', which stated 'we must take particular care of scientists . . . who have made great contributions. Efforts should be made to transform slowly their world outlook and their style of work'. This protection did not last, as the pressures for egalitarianism and Chairman Mao's philosophy bit more deeply ('Intellectuals specialising in engineering are better, because they are in touch with reality. Pure scientists are worse, but are still better than those who specialise in the arts. Students of history, philosophy and economics have no concern with studying reality - they are the most ignorant').

The results of these upheavals are now widely known to a growing band of people. And amongst these there has been strong criticism of reduced academic standards, together with muted approval for the science-for-thepeople approach. But in the past few years the tide seems again to have been moving slowly the other way, and probably with Mao's death (which came after this seminar had occurred) will move a little quicker. China may start again to walk even more evenly on two legs; this report will provide an excellent guide for the onlookers. 